\title{
Faunistic analysis of pest insects and their natural enemies associated with hairy fleabane in soybean crop ${ }^{1}$
}

\author{
Giliardi Dalazen², Maurício Bigolin ${ }^{3}$, Ivair Valmorbida ${ }^{4}$, Regis Felipe Stacke ${ }^{4}$, Deise Cagliari ${ }^{5}$
}

\section{ABSTRACT}

In addition to competing with crops, weeds can provide shelter for arthropods in cropping fields and adjacent areas. This study aimed to investigate the occurrence and population fluctuation of insect pests and their natural enemies associated with hairy fleabane (Conyza spp.), in soybean farming areas. The predominant species were Schizaphis graminum, Taylorilygus apicalis, Empoasca spp. and Nysius simulans. Species that comprise important pest complexes, including stink bugs and caterpillars, can develop on fleabane plants. Among them, the stink bugs Edessa meditabunda, Dichelops spp., Piezodorus guildinii, Nezara viridula and Euschistus heros, as well as the caterpillars Anticarsia gemmatalis, Spodoptera frugiperda, Spodoptera eridania, Chrysodeixis includens and Helicoverpa spp. have prevailed. The most common natural enemies were Orius spp., Eriopis connexa, Cycloneda sanuiinea and Chrysoperla spp. The population fluctuation analysis indicated that hairy fleabane mainly hosted stink bugs at the beginning of the crop cycle and after soybean maturation. The caterpillars, however, use this weed as an alternative host throughout the crop cycle, continuing after soybean maturation and harvesting. For natural enemies species, the population fluctuation depends on the occurrence of insects that serve as a food source for them. Thus, it is possible to conclude that hairy fleabane is an important alternative host for pest insects and their natural enemies in soybean crops.

KEYWORDS: Conyza spp.; biodiversity; alternative host; weeds; population fluctuation.

\section{INTRODUCTION}

Weeds are known to interfere with crops largely due to competition for water, light and nutrients. However, in addition to competing for essential

\section{RESUMO}

Análise faunística de insetos-praga e seus inimigos naturais associados a buva em cultivo de soja

Além de competirem com as culturas, as plantas daninhas podem servir de abrigo para artrópodes, em lavouras e áreas adjacentes. Objetivou-se estudar a ocorrência e flutuação populacional de insetos-praga e inimigos naturais associados a buva (Conyza spp.), em áreas de cultivo de soja. As espécies predominantes foram Schizaphis graminum, Taylorilygus apicalis, Empoasca spp. e Nysius simulans. Espécies que compreendem complexos importantes de pragas, incluindo percevejos e lagartas, são capazes de se desenvolver sobre plantas dessa espécie daninha. Dentre elas, prevaleceram os percevejos Edessa meditabunda, Dichelops spp., Piezodorus guildinii, Nezara viridula e Euschistus heros, e as lagartas Anticarsia gemmatalis, Spodoptera frugiperda, Spodoptera eridania, Chrysodeixis includens e Helicoverpa spp. Os inimigos naturais mais encontrados foram Orius spp., Eriopis connexa, Cycloneda sanuiinea e Chrysoperla spp. A análise de flutuação populacional indicou a ocorrência de percevejos sobre plantas de buva, sobretudo no período inicial do cultivo e após a maturação da soja. Já as lagartas utilizam esta planta como hospedeiro alternativo durante todo o ciclo da cultura, continuando após a maturação e colheita da soja. Para os inimigos naturais, a flutuação das espécies depende da ocorrência de insetos que lhes servem como fonte de alimento. Logo, é possível concluir que a buva é um importante hospedeiro alternativo de insetos-praga e seus inimigos naturais, em cultivo de soja.

PALAVRAS-CHAVE: Conyza spp.; biodiversidade; hospedeiro alternativo; plantas daninhas; flutuação populacional.

resources, these plants may serve as alternative hosts for pest insects and their natural enemies, providing shelter or a food source (Norris \& Kogan 2005, Caballero-López et al. 2012). Examples include Chaetopsis massyla Walker (Diptera: Otitidae) and

1. Manuscript received in Jun./2017 and accepted for publication in Sep./2017 (http://dx.doi.org/10.1590/1983-40632016v4747348).

2. Universidade Estadual de Londrina, Centro de Ciências Agrárias, Departamento de Agronomia, Londrina, PR, Brasil. E-mail: giliardidalazen@gmail.com.

3. Universidade Federal do Oeste do Pará, Instituto de Biodiversidade e Florestas, Santarém, PA, Brasil.

E-mail: mauricio.bigolin@ufopa.edu.br.

4. Universidade Federal de Santa Maria, Centro de Ciências Rurais, Departamento de Defesa Fitossanitária, Santa Maria, RS, Brasil.E-mails: ivairvalmorbida@gmail.com, regis_felip@hotmail.com.

5. Universidade Federal de Pelotas, Faculdade de Agronomia Eliseu Maciel, Departamento de Fitossanidade, Pelotas, RS, Brasil. E-mail: deisycagliari@yahoo.com.br. 
Euxesta spp. (Diptera: Otitidae), important corn pests that can develop on Amaranthus spinosus, Portulaca oleracea, Sorghum halepense and Typha spp. (Goyal et al. 2012). Furthermore, the rice pest Oebalus pugnax Fabricius (Hemiptera: Pentatomidae) shows a high survival rate on the weed Echinochloa colona, which serves as a food source (Awuni et al. 2014). In some cases, weeds serve as hosts for insect vectors of viral and bacterial diseases (Eziashi et al. 2013).

Panizzi (1997) presented an extensive review about the role of alternative hosts, including weeds, on the biology of stink bugs. According to the author, most Pentatomidae species spend only a third of their life feeding on crops. The remaining time is spent feeding or reproducing on wild hosts, or occupying hibernation sites provided by those hosts.

Despite the use of herbicides, weeds are of common occurrence in soybean crops. This may be due to flaws in the application, tolerance or herbicide-resistant species. Hairy fleabane (Conyza spp. Asteraceae) is an important weed in soybean crops worldwide, and may cause significant yield losses (Trezzi et al. 2015). An annual plant, it can produce up to 200 thousand seeds per plant, which are easily dispersed by wind (Moreira et al. 2007). Over the last decade, hairy fleabane has proved difficult to control due to the selection of populations resistant to glyphosate, an herbicide widely used for weed control in soybean crops (Vargas et al. 2007, Christoffoleti et al. 2008, Lamego \& Vidal 2008). Hairy fleabane seedlings emerge twice a year, in the fall and spring, when temperatures range $20-25^{\circ} \mathrm{C}$, an ideal condition for germination (Lazarotto et al. 2008, Zambrano-Navea et al. 2013).

It is common year-round in crops in southern Brazil, since, in addition to an inefficient control in the summer growing season, areas designated as pastures or left fallow in the off-season are typically not treated for weeds. The lack of efficient control means that these plants persist throughout the year, serving as hosts for pest insects and their natural enemies. This scenario has worsened as the cropping of glyphosate-resistant soybean expands and other weed populations decline, making hairy fleabane plants a rare source of shelter and food for insects and other invertebrates. Thus, the absence of preferential hosts means insects using these plants as secondary hosts or shelter, serving as "green bridges" to other crops. As such, the population of pest insects may be high when economically important crops are sown.
Reports of pest insects on hairy fleabane plants are common among farmers. However, an in-depth study on the presence of arthropods on this important weed has yet to be conducted in southern Brazil. Therefore, this study aimed to assess the arthropod fauna (pest insects and their natural enemies) and its population fluctuation, associated with hairy fleabane plants (Conyza spp.), in soybean crops.

\section{MATERIAL AND METHODS}

The study was carried out in two fields, one in São Vicente do Sul (2943'58''S; 5441'42'W), in the central depression region of the Rio Grande do Sul state, Brazil, and the other in Boa Vista do Incra (28 $56^{\prime} 06^{\prime \prime} \mathrm{S}$; 53⒉ $\left.26^{\prime} 08^{\prime \prime} \mathrm{W}\right)$, in the middle plateau region of the same state. These areas covered 5.1 and 6.8 hectares, respectively. The fields are used as pasture for breeding and fattening cattle during the winter season (June to September) and for soybean cropping in the summer (October to May). This system is representative of the management practices used in most farms from this Brazilian state.

Sampling was performed every two weeks, starting when the soybean was sowed (November 2010) and continuing through the winter pasture period (black oat and annual ryegrass) and into the growing season in the following year (November 2011). In all, there were 21 samplings at each site. One hundred plants randomly collected at each site were analyzed at each assessment. Collections were carried out by quickly bagging whole plants (Byerly et al. 1978), to prevent arthropods from escaping, and cutting them close to the ground. Next, the specimens present on each plant were identified and counted.

The larvae were raised to adulthood, in order to confirm the species identification. Larvae were fed with an artificial diet (Kasten Junior et al. 1978), plus soybean and hairy fleabane leaves, under a temperature of $25 \pm 1{ }^{\circ} \mathrm{C}, 65 \pm 5 \%$ relative humidity and 14 -h light phase. The specimens were taxonomically identified for genus and/or species, except those belonging to the Tettigoniidae and Syrphidae families and Araneae order. Some species were identified using taxonomic keys, and this identification was confirmed by Dr. Diego Leonardo Carpintero from the Bernardino Rivadavia Natural Sciences Argentine Museum, in Buenos Aires, Argentina.

Dominance, abundance, frequency and constancy, as well as measures of diversity (H index 
of Shannon-Weaner), species richness (Margalef's index) and uniformity or equitability were calculated. To dominance, the identified taxa were classified as dominant, non-dominant or super dominant. Abundance was categorized as rare, dispersed, common, abundant, very abundant and super abundant. The frequency classes were: infrequent, frequent, very frequent and super frequent. In relation to constancy, taxa were classified as constant, accessory and accidental. The similarity (Jaccard index) between the Boa Vista do Incra and São Vicente do Sul communities was also assessed. The data were analyzed using the Anafau software (Moraes \& Haddad 2003).

\section{RESULTS AND DISCUSSION}

The results obtained in both sites indicate that hairy fleabane plants serve as hosts and food sources for several arthropod species across different orders, including agriculturally important species. In Boa Vista do Incra (Table 1), 5,430 specimens were collected, from nine orders. The predominant species were: Schizaphis graminum Rondani (Hemiptera: Aphididae) (greenbug) with 1,590 individuals, Taylorilygus apicalis Fieber (Hemiptera: Miridae) (broken-backed bug) with 1,926 individuals, Empoasca spp. (Hemiptera: Cicadellidae) (leafhopper) with 536 individuals,

Table 1. Faunal analysis of arthropods associated with hairy fleabane plants (Conyza spp.) in Boa Vista do Incra, Rio Grande do Sul state, Brazil.

\begin{tabular}{|c|c|c|c|c|c|c|c|}
\hline Order & Species, genus or family & $\mathrm{N}^{1}$ & Samples $^{2}$ & Dominance $^{3}$ & Abundance ${ }^{4}$ & Frequency $^{5}$ & Constancy $^{6}$ \\
\hline \multirow{13}{*}{ Hemiptera } & Edessa meditabunda & 76 & 14 & $\mathrm{D}$ & $\mathrm{c}$ & $\mathrm{f}$ & $\mathrm{W}$ \\
\hline & Dichelops spp. & 4 & 2 & ND & $\mathrm{r}$ & if & $\mathrm{Z}$ \\
\hline & Piezodorus guildinii & 4 & 1 & ND & $\mathrm{r}$ & if & $\mathrm{Z}$ \\
\hline & Nezara viridula & 1 & 1 & ND & $\mathrm{r}$ & if & $\mathrm{Z}$ \\
\hline & Euschistus heros & 12 & 4 & $\mathrm{D}$ & d & if & $\mathrm{Z}$ \\
\hline & Nysius simulans & 29 & 8 & $\mathrm{D}$ & $\mathrm{c}$ & $\mathrm{f}$ & $\mathrm{Y}$ \\
\hline & Taylorilygus apicalis* & 1,926 & 18 & SD & sa & sf & $\mathrm{W}$ \\
\hline & Orius spp. & 62 & 5 & $\mathrm{D}$ & $\mathrm{c}$ & $\mathrm{f}$ & $\mathrm{Z}$ \\
\hline & Geocoris spp. & 1 & 1 & ND & $\mathrm{r}$ & if & $\mathrm{Z}$ \\
\hline & Atrachelus cinereus & 3 & 1 & ND & $\mathrm{r}$ & if & $\mathrm{Z}$ \\
\hline & Schizaphis graminum* & 1,590 & 14 & SD & sa & sf & W \\
\hline & Toxoptera citricidus & 362 & 4 & $\mathrm{D}$ & va & $\mathrm{vf}$ & $\mathrm{Z}$ \\
\hline & Empoasca spp.* & 536 & 21 & $\mathrm{D}$ & va & $\mathrm{vf}$ & $\mathrm{W}$ \\
\hline \multirow{8}{*}{ Lepidoptera } & Anticarsia gemmatalis & 86 & 10 & $\mathrm{D}$ & $\mathrm{c}$ & $\mathrm{f}$ & $\mathrm{Y}$ \\
\hline & Spodoptera frugiperda & 63 & 11 & $\mathrm{D}$ & $\mathrm{c}$ & $\mathrm{f}$ & W \\
\hline & Spodoptera eridania & 4 & 2 & ND & $\mathrm{r}$ & if & $\mathrm{Z}$ \\
\hline & Chrysodeixis includens & 47 & 12 & $\mathrm{D}$ & $\mathrm{c}$ & f & W \\
\hline & Heliothis virescens & 3 & 1 & ND & $\mathrm{r}$ & if & $\mathrm{Z}$ \\
\hline & Helicoverpa gelotopoeon & 2 & 1 & ND & $\mathrm{r}$ & if & Z \\
\hline & Argyrotaenia spp. & 79 & 8 & $\mathrm{D}$ & $\mathrm{c}$ & $\mathrm{f}$ & $\mathrm{Y}$ \\
\hline & Caloreas spp. & 118 & 8 & $\mathrm{D}$ & va & $\mathrm{vf}$ & $\mathrm{Y}$ \\
\hline \multirow{5}{*}{ Coleoptera } & Diabrotica speciosa & 14 & 4 & $\mathrm{D}$ & d & if & $\mathrm{Z}$ \\
\hline & Astylus variegatus & 36 & 3 & $\mathrm{D}$ & $\mathrm{c}$ & $\mathrm{f}$ & $\mathrm{Z}$ \\
\hline & Eriopis connexa & 46 & 7 & $\mathrm{D}$ & $\mathrm{c}$ & f & $\mathrm{Y}$ \\
\hline & Cycloneda sanguinea & 19 & 8 & $\mathrm{D}$ & d & if & $\mathrm{Y}$ \\
\hline & Hippodamia convergens & 1 & 1 & ND & $\mathrm{r}$ & if & $\mathrm{Z}$ \\
\hline Neuroptera & Chrysoperla spp. & 59 & 7 & $\mathrm{D}$ & $\mathrm{c}$ & f & $\mathrm{Y}$ \\
\hline Orthoptera & Tettigoniidae & 5 & 5 & ND & $\mathrm{r}$ & if & $\mathrm{Z}$ \\
\hline Diptera & Syrphidae & 73 & 7 & $\mathrm{D}$ & $\mathrm{c}$ & $\mathrm{f}$ & $\mathrm{Y}$ \\
\hline Thysanoptera & Frankliniella spp. & 36 & 8 & $\mathrm{D}$ & $\mathrm{c}$ & $\mathrm{f}$ & $\mathrm{Y}$ \\
\hline Hymenoptera & Cotesia flavipes & 6 & 3 & $\mathrm{D}$ & $\mathrm{r}$ & if & Z \\
\hline Araneae & Spiders* & 127 & 17 & $\mathrm{D}$ & va & $\mathrm{vf}$ & $\mathrm{W}$ \\
\hline
\end{tabular}


and 127 spiders. The two first species exhibited the highest faunal indices, classified as super dominant, super abundant, super frequent and constant.

In São Vicente do Sul (Table 2), 8,420 specimens were collected, from nine orders. The predominant species were: $S$. graminum (5,429 individuals), T. apicalis (1,313 individuals), Empoasca spp. (672 individuals), spiders (245 individuals) and Nysius simulans Stål (Hemiptera: Lygaeidae) (true bug), with 208 individuals. The species T. Apicalis, S. graminum and Empoasca spp. displayed the highest faunal indices, classified as super dominant, super abundant, super frequent and constant.

Toxoptera citricidus Kirkaldy (Hemiptera: Aphididae) (brown citrus aphid) and S. graminum were very common in both sites (Boa Vista do Incra and São Vicente do Sul). The latter species predominated and presented the highest number of individuals. In Boa Vista do Incra, approximately
$35 \%$ of the collected specimens were aphids, whereas these insects accounted for around $65 \%$ of the total in São Vicente do Sul. Aphids were primarily observed on hairy fleabane stems and were less frequent on the leaves and reproductive organs of the plant. Its occurrence was predominant during the winter pasture stage, from April to August (Figure 1). Aphids are an important pest in winter grains and a major cause of yield loss in wheat crops (Roza-Gomes et al. 2008). These sap-sucking insects may cause direct damage by feeding on phloem sap and indirect damage as vectors of the barley yellow dwarf virus (Salvadori \& Tonet 2001).

Natural enemies, such as Coccinellidae, known as ladybugs, were also observed (Figure 2) feeding on the aphids. Although aphids are important pests, their association with hairy fleabane plants may be positive, since they attract natural enemies that can remain on the crop, helping to balance pest populations. Both juvenile (larvae) and adult

Table 2. Faunal analysis of arthropods associated with hairy fleabane plants (Conyza spp.) in São Vicente do Sul, Rio Grande do Sul state, Brazil.

\begin{tabular}{|c|c|c|c|c|c|c|c|}
\hline Order & Species, genus or family & $\mathrm{N}^{1}$ & Samples $^{2}$ & Dominance $^{3}$ & Abundance $^{4}$ & Frequency $^{5}$ & Constancy $^{6}$ \\
\hline \multirow{10}{*}{ Hemiptera } & Edessa meditabunda & 1 & 1 & ND & $\mathrm{r}$ & if & $\mathrm{Z}$ \\
\hline & Piezodorus guildinii & 5 & 3 & ND & $\mathrm{r}$ & if & $\mathrm{Z}$ \\
\hline & Nysius simulans* & 208 & 12 & $\mathrm{D}$ & va & $\mathrm{vf}$ & $\mathrm{W}$ \\
\hline & Taylorilygus apicalis* & 1,313 & 18 & SD & sa & sf & $\mathrm{W}$ \\
\hline & Orius spp. & 10 & 6 & $\mathrm{D}$ & $\mathrm{r}$ & if & $\mathrm{Y}$ \\
\hline & Geocoris spp. & 36 & 7 & $\mathrm{D}$ & $\mathrm{c}$ & $\mathrm{f}$ & $\mathrm{Y}$ \\
\hline & Atrachelus cinereus & 2 & 2 & ND & $\mathrm{r}$ & if & $\mathrm{Z}$ \\
\hline & Schizaphis graminum* & 5,429 & 14 & SD & sa & sf & W \\
\hline & Toxoptera citricidus & 28 & 2 & $\mathrm{D}$ & $\mathrm{c}$ & $\mathrm{f}$ & $\mathrm{Z}$ \\
\hline & Empoasca spp.* & 672 & 21 & SD & sa & sf & W \\
\hline \multirow{7}{*}{ Lepidoptera } & Anticarsia gemmatalis & 22 & 6 & $\mathrm{D}$ & $\mathrm{c}$ & $\mathrm{f}$ & $\mathrm{Y}$ \\
\hline & Spodoptera frugiperda & 23 & 7 & $\mathrm{D}$ & $\mathrm{c}$ & $\mathrm{f}$ & $\mathrm{Y}$ \\
\hline & Chrysodeixis includens & 18 & 5 & $\mathrm{D}$ & d & if & $\mathrm{Z}$ \\
\hline & Heliothis virescens & 5 & 1 & ND & $\mathrm{r}$ & if & $\mathrm{Z}$ \\
\hline & Helicoverpa zea & 1 & 1 & ND & $\mathrm{r}$ & if & $\mathrm{Z}$ \\
\hline & Argyrotaenia spp. & 48 & 4 & $\mathrm{D}$ & $\mathrm{c}$ & $\mathrm{f}$ & $\mathrm{Z}$ \\
\hline & Caloreas spp. & 72 & 8 & $\mathrm{D}$ & $\mathrm{a}$ & $\mathrm{vf}$ & $\mathrm{Y}$ \\
\hline \multirow{3}{*}{ Coleoptera } & Diabrotica speciosa & 9 & 5 & $\mathrm{D}$ & $\mathrm{r}$ & if & $\mathrm{Z}$ \\
\hline & Eriopis connexa & 34 & 10 & $\mathrm{D}$ & $\mathrm{c}$ & $\mathrm{f}$ & $\mathrm{Y}$ \\
\hline & Cycloneda sanguinea & 38 & 9 & $\mathrm{D}$ & $\mathrm{c}$ & $\mathrm{f}$ & $\mathrm{Y}$ \\
\hline Neuroptera & Chrysoperla spp. & 20 & 8 & $\mathrm{D}$ & $\mathrm{c}$ & $\mathrm{f}$ & $\mathrm{Y}$ \\
\hline Orthoptera & Tettigoniidae & 17 & 11 & $\mathrm{D}$ & $\mathrm{d}$ & if & $\mathrm{W}$ \\
\hline Diptera & Syrphidae & 52 & 8 & $\mathrm{D}$ & $\mathrm{c}$ & $\mathrm{f}$ & $\mathrm{Y}$ \\
\hline Thysanoptera & Frankliniella spp. & 38 & 4 & $\mathrm{D}$ & $\mathrm{c}$ & $\mathrm{f}$ & $\mathrm{Z}$ \\
\hline Hymenoptera & Cotesia flavipes & 74 & 10 & $\mathrm{D}$ & $\mathrm{a}$ & $\mathrm{vf}$ & $\mathrm{Y}$ \\
\hline Araneae & Spiders* & 245 & 18 & $\mathrm{D}$ & va & $\mathrm{vf}$ & $\mathrm{W}$ \\
\hline
\end{tabular}


Eriopis connexa Germar (Coleoptera: Coccinellidae), Cycloneda sanguinea Linnaeus (Coleoptera: Coccinellidae) and Hippodamia convergens Guérin-Méneville (Coleoptera: Coccinellidae) were also present. Other important natural enemies in agricultural systems were also observed: Geocoris spp. (Hemiptera: Geocoridae) (bigeyed bug), Chrysoperla spp. (Neuroptera: Chrysopidae) (green lacewing), Cotesia flavipes Cameron (Hymenoptera: Braconidae) (braconid wasp) and Orius spp. (Hemiptera: Anthocoridae) (insidious flower bug).

A large number of the true bugs $T$. apicalis and $N$. simulans were also identified, mainly in São Vicente do Sul. Despite being native to Africa, T. apicalis is a common species in South America (Logarzo et al. 2005). It is polyphagous and may attack bean, lettuce, cotton, sunflower and other

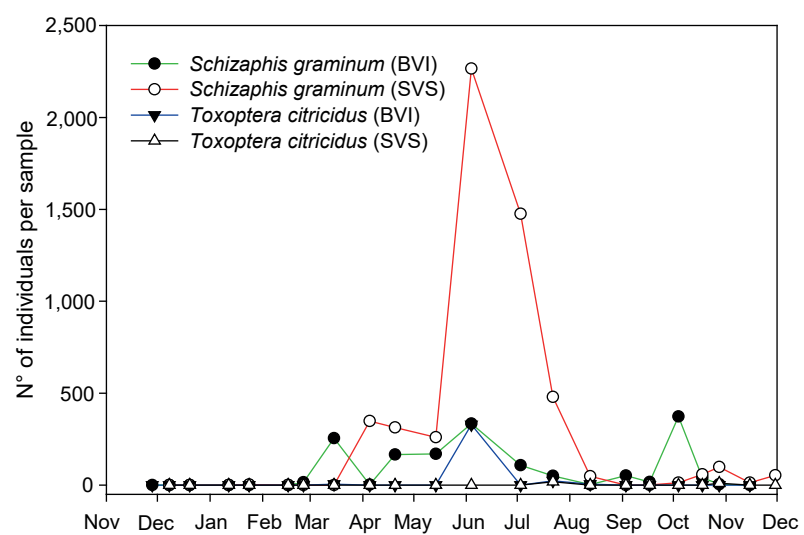

Figure 1. Population fluctuation of aphids on hairy fleabane plants (Conyza spp.) in Boa Vista do Incra (BVI) and São Vicente do Sul (SVS), Rio Grande do Sul state, Brazil. crops. Moreover, it also acts as a natural enemy, typically feeding on Lepidopteran eggs and small larvae (Bailey et al. 2007). The stink bug N. simulans, known as "chinche diminuta" in Spanish, has been observed in soybean crops in Argentina (Molinari \& Gamundi 2010). The cropping fields attacked by these pests show severe damage in the initial growth stages. Although they are known to feed on seeds, stink bugs often cause damage to vascular tissue, and much of that occurs when they migrate from the host weeds to crops, particularly during periods of drought (Molinari \& Gamundi 2010).

In this study, the population fluctuation of T. apicalis and $N$. simulans (Figure 3 ) was characterized by their occurrence at the beginning of the soybean crop cycle (November and December) and during the reproductive period (March and April). The presence of $N$. simulans on soybean crops in the Rio Grande do Sul state alert to the monitoring of these pests in the coming growing seasons. Early desiccation of areas infested with hairy fleabane could prevent the occurrence of these and other pests.

The orders with the highest number of species were Hemiptera and Lepidoptera, which were the same orders found in the two main soybean pest complexes: stink bugs and caterpillars. Five species of common soybean stink bugs were observed: Edessa meditabunda Fabricius (Hemiptera: Pentatomidae) (brown-winged stink bug), Dichelops spp. (Hemiptera: Pentatomidae) (green-belly stink bug), Piezodorus guildinii Westwood (Hemiptera: Pentatomidae) (red-banded stink bug), Nezara viridula Linnaeus (Hemiptera: Pentatomidae) (southern green stink bug) and Euschistus heros
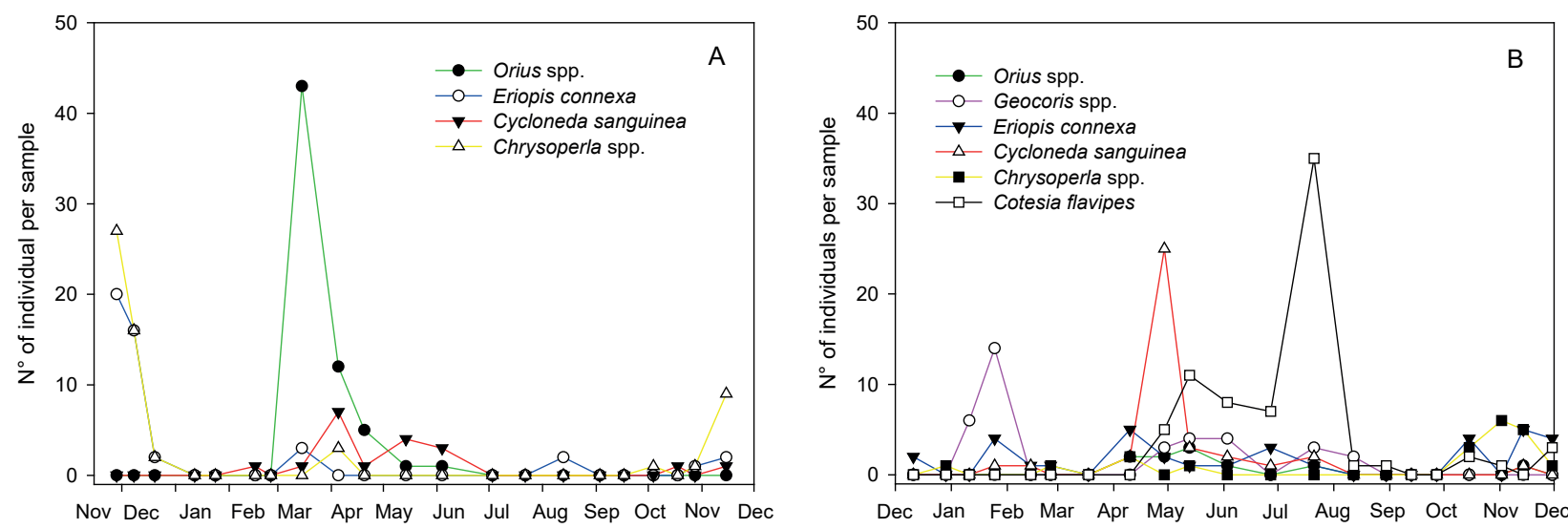

Figure 2. Population fluctuation of natural enemies on hairy fleabane plants (Conyza spp.) in Boa Vista do Incra (A) and São Vicente do Sul (B), Rio Grande do Sul state, Brazil. 
Fabricius (Hemiptera: Pentatomidae) (neotropical brown stink bug). The species E. meditabunda and $E$. heros were dominant in Boa Vista do Incra. Stink bugs compromise soybean yield and quality by sucking the sap from the plants through their mouthpiece and transmitting diseases. Damage begins from the formation of pods, and grains attacked are smaller, wrinkled, cracked and darker in color (Hoffmann-Campo et al. 2000).

The largest number of pentatomid stink bugs found on hairy fleabane plants in this study were from the E. meditabunda species, which, despite being a secondary pest for soybean, occasionally causes considerable crop damage in the Rio Grande do Sul state and the Brazilian midwest region (CorrêaFerreira \& Panizzi 1999). Its low damage potential is due to the fact that it does not feed exclusively on grains, but also on soybean stems, differently from other stink bugs that attack this crop. This fact may explain its high occurrence in hairy fleabane plants, since it was observed feeding on the stems of this weed. The other dominant species (E. heros), although it is the least polyphagous among important soybean pests, has also been observed on alternative host plants, such as Euphorbia heterophylla (milkweed) (Hoffmann-Campo et al. 2000).

The occurrence of phytophagous stink bugs on hairy fleabane plants (Figure 4) did not coincide with the intermediate stages of the soybean reproductive cycle, which is preferable for these insects. The highest occurrence was recorded after the crop reached physiological maturity (March), prompting the insects to move from the mature soybean plants (stages R7 and R8) to green hairy fleabane plants, where they complete another generation before entering diapause. At this stage, soybean becomes
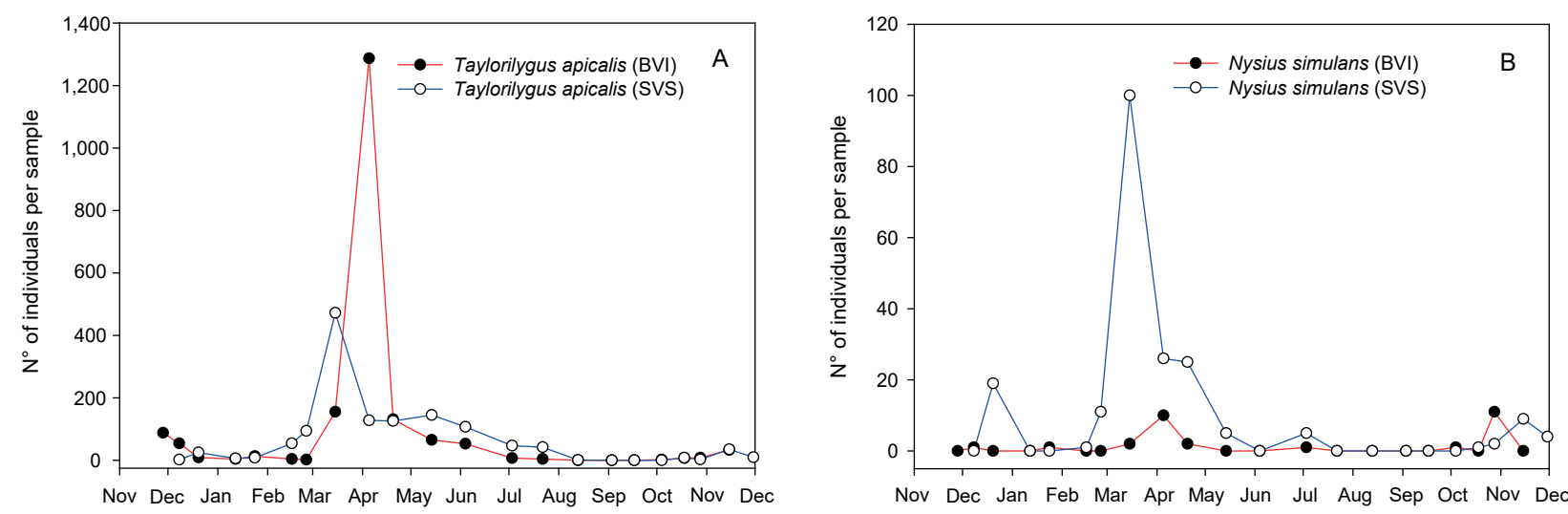

Figure 3. Population fluctuation of Taylorilygus apicalis (A) and Nysius simulans (B) on hairy fleabane plants (Conyza spp.) in Boa Vista do Incra (BVI) and São Vicente do Sul (SVS), Rio Grande do Sul state, Brazil.
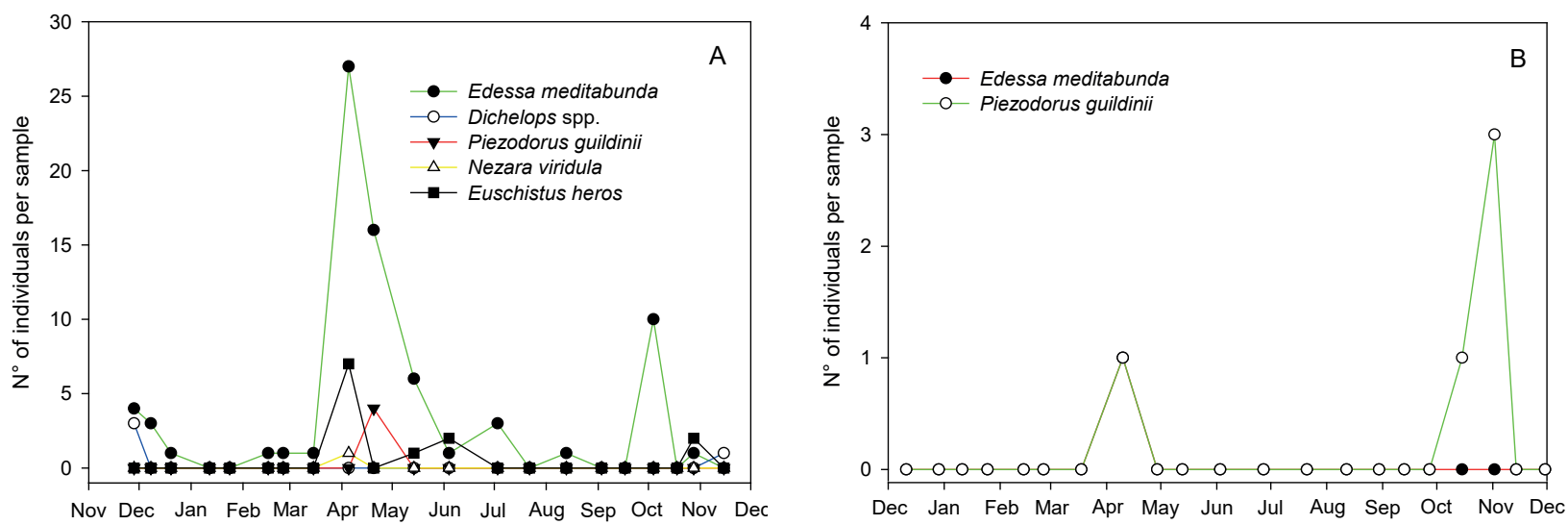

Figure 4. Population fluctuation of stink bugs on hairy fleabane plants (Conyza spp.) in Boa Vista do Incra (A) and São Vicente do Sul (B), Rio Grande do Sul state, Brazil. 
unsuitable for consumption, because of the hard integument and pod thickness (Panizzi 1991).

In regard to caterpillars, the main species considered soybean pests were collected on hairy fleabane plants in this study: Anticarsia gemmatalis Hübner (Lepidoptera: Noctuidae) (velvetbean caterpillar), Spodoptera frugiperda Smith (Lepidoptera: Noctuidae) (fall armyworm), Spodoptera eridania Cramer (Lepidoptera: Noctuidae) (southern armyworm), Chrysodeixis includens Walker (Lepidoptera: Noctuidae) (soybean looper), Helicoverpa zea Boddie (Lepidoptera: Noctuidae) (corn earworm), Helicoverpa gelotopoeon Dyar (Lepidoptera: Noctuidae) (bollworm moth) and Heliothis virescens Fabricius (Lepidoptera: Noctuidae) (tobacco budworm). The dominant caterpillar species in both sites were A. gemmatalis, $S$. frugiperda and C. includens. These caterpillars are considered important pests in soybean and other cash crops, causing defoliation, which reduces the photosynthetic area and photosynthate production, in addition to attacking the reproductive structures, especially seeds (Hoffmann-Campo et al. 2000, Barros et al. 2010).

The population fluctuation of caterpillars indicated that, in both places, these pests were present during almost the entire growing season (from sowing, in November, until harvesting, in early April), even extending into June (Figure 5). A. gemmatalis was one of the dominant species in both sites. This Lepidopteran is the main defoliation pest of soybean crops in Brazil (Hoffmann-Campo et al. 2000, Panizzi et al. 2004), and hairy fleabane showed to be an important secondary host for this caterpillar, as well as to $S$. frugiperda. Although the latter species is the predominant pest in corn crops, in recent growing seasons, it has been observed damaging soybean leaves and pods (Barros et al. 2010). According to Mendes et al. (2016), the presence of hairy fleabane from May to September serves as a food source for $S$. frugiperd $a$; however, the insect is unable to complete its cycle when feeding only on leaves of this weed. Species belonging to the genera Spodoptera and Helicoverpa were more common during the soybean pod-setting period, corroborating observations by the aforementioned authors.

Other Lepidopterans, such as Argyrotaenia spp. (Lepidoptera: Tortricidae) and Caloreas spp. (Lepidoptera: Choreutidae), were also observed feeding on hairy fleabane plants. They are known to attack fruit species such as persimmons, grapes and peaches (Bavaresco et al. 2005), highlighting the importance of keeping orchards free of this weed to prevent the occurrence of these pests. Caloreas cydrota Meyrick (Lepidoptera: Choreutidae) has been reported on hairy fleabane in orchards in the Paraná state, Brazil, with the same weed serving as its food source and shelter (Bortolotto et al. 2015).

Therefore, hairy fleabane plants are an alternative host for the insect pests present in the soybean farming system in southern Brazil, along with natural enemies and pests that attack other crops. In addition to competing for light, water and nutrients, this weed may also compromise crops by serving as a host for important agricultural pests, providing a "green bridge" between crops. Thus, the winter control of hairy fleabane and early

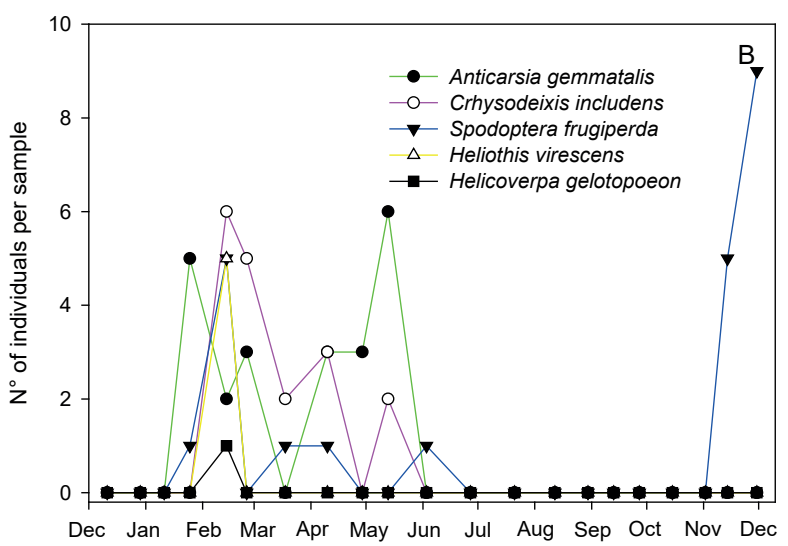

Figure 5. Population fluctuation of caterpillars on hairy fleabane plants (Conyza spp.) in Boa Vista do Incra (A) and São Vicente do Sul (B), Rio Grande do Sul state, Brazil. 
Table 3. Faunal indices for arthropods associated with hairy fleabane plants (Conyza spp.) in Boa Vista do Incra and São Vicente do Sul, Rio Grande do Sul state, Brazil.

\begin{tabular}{cccccc}
\hline Site & Number of individuals & Number of species & Diversity Index & Richness index & Equity index \\
\hline Boa Vista do Incra & 5,430 & 32 & 2.50 & 3.84 & 0.73 \\
\hline São Vicente do Sul & 8,420 & 26 & 2.49 & 3.18 & 0.79 \\
\hline
\end{tabular}

desiccation should be adopted to reduce insect pest populations.

A comparison of the faunal indices for both studied sites (Table 3) demonstrates that the diversity indices of Shannon-Weaner were almost the same, with 2.50 recorded in Boa Vista do Incra and 2.49 in São Vicente do Sul. This index generally varies between 1.5 and 3.5, with the highest value indicating maximum diversity. The species richness index for Boa Vista do Incra was 3.84, higher than that recorded in São Vicente do Sul (3.18). This indicates a greater species richness for arthropods found on hairy fleabane plants in the first place, since specimens were gathered into 32 groups, when compared to 26 in São Vicente do Sul. The uniformity or equitability indices also varied slightly between sites (Boa Vista do Incra: 0.73; São Vicente do Sul: 0.79), with uniformity slightly greater in São Vicente do Sul. This index ranges from 0 to 1 , where the highest value indicates that all species exhibit the same abundance. As such, specimens in São Vicente do Sul were the most uniformly distributed among the species found.

The analysis of similarities indicated $89.7 \%$ between Boa Vista do Incra and São Vicente do Sul, concerning the arthropods collected on hairy fleabane plants during the study period. Of the total number of groups found, 26 were common to both locations studied. This indicates an agreement between the results obtained from the different areas, corroborating that hairy fleabane is an important host of pest insects and their natural enemies in soybean crops of the studied region.

\section{CONCLUSIONS}

1. Important soybean pest insects, including the stink bugs Edessa meditabunda, Dichelops spp., Piezodorus guildinii, Nezara viridula and Euschistus heros, and the caterpillars Anticarsia gemmatalis, Spodoptera frugiperda, Spodoptera eridania, Chrysodeixis includens and Helicoverpa spp. are found on hairy fleabane plants (Conyza spp.). The natural enemies Eriopis connexa, Cycloneda sanguinea, Hippodamia convergens, Geocoris spp., Chrysoperla spp., Cotesia flavipes and Orius spp. also use this same weed as an alternative host;

2. The population fluctuation of the pest insects indicates that hairy fleabane serves as a food source and host for stink bugs at the beginning of the crop cycle and after soybean maturation. But, to caterpillars, this weed serves as an alternative host throughout the crop cycle, continuing after soybean maturation and harvesting. In natural enemies, species fluctuation depends on the occurrence of insects that serve as a food source for them.

\section{REFERENCES}

AWUNI, G. A. et al. Host preference and suitability of grasses for Oebalus pugnax. Entomologia Experimentalis et Applicata, v. 152, n. 2, p. 127-134, 2014.

BAILEY, P. T. et al. Pests of field crops and pastures: identification and control. Collingwood: CSIRO Publishing, 2007.

BARROS, E. M. et al. Development of Spodoptera frugiperda on different hosts and damage to reproductive structures in cotton. Entomologia Experimentalis et Applicata, v. 137, n. 3, p. 237-245, 2010.

BAVARESCO, A. et al. Biologia e reprodução de Argyrotaenia sphaleropa (Meyrick, 1909) (Lepidoptera: Tortricidae) em folhas de caquizeiro, macieira e videira. Arquivos do Instituto Biológico, v. 72, n. 3, p. 365-372, 2005.

BORTOlOtTO, O. C.; SILVA, G. V.; BUENO, A. F. First report of the microlepidopteran Caloreas cydrota (Meyrick, 1915) (Lepidoptera: Choreutidae) in Brazil. Brazilian Journal of Biology, v. 75, n. 4, suppl. 1, p. S258, 2015.

BYERLY, K. F. et al. A comparison of sampling methods for some arthropod populations in cotton. Hilgardia, v. 46, n. 8, p. 257-282, 1978.

CABALLERO-LÓPEZ, B. et al. Weeds, aphids, and specialist parasitoids and predators benefit differently 
from organic and conventional cropping of winter cereals. Journal of Pest Science, v. 85, n. 1, p. 81-88, 2012.

CHRISTOFFOLETI, P. J. et al. Glyphosate sustainability in South American cropping systems. Pest Management Science, v. 64, n. 4, p. 422-427, 2008.

CORRÊA-FERREIRA, B. S.; PANIZZI, A. R. Percevejos da soja e seu manejo. Londrina: Embrapa-CNPSo, 1999.

EZIASHI, E. I. et al. Potential weed species as alternate hosts of insect vectors of the lethal yellowing disease (LYD) of coconut palms (Cocos nucifera L.) in Nigeria. British Journal of Applied Science \& Technology, v. 3, n. 1, p. 123-130, 2013.

GOYAL, G. et al. Alternative plants for development of picture-winged fly pests of maize. Entomologia Experimentalis et Applicata, v. 143, n. 2, p. 177-184, 2012.

HOFFMANN-CAMPO, C. B. et al. Pragas da soja no Brasil e seu manejo integrado. Londrina: Embrapa Soja, 2000.

KASTEN JUNIOR, P.; PRECETTI, A. A. C. M.; PARRA, J. R. P. Dados biológicos comparativos de Spodoptera frugiperda (J. E. SMITH, 1797) em duas dietas artificiais e substrato natural. Revista de Agricultura, v. 53, n. 1-2, p. 69-78, 1978.

LAMEGO, F. P.; VIDAL, R. A. Resistência ao glyphosate em biótipos de Conyza bonariensis e Conyza canadensis no Estado do Rio Grande do Sul, Brasil. Planta Daninha, v. 26, n. 2, p. 467-471, 2008.

LAZAROTO, C. A. et al. Biologia e ecofisiologia de buva (Conyza bonariensis e Conyza canadensis). Ciência Rural, v. 38, n. 3, p. 852-860, 2008.

LOGARZO, G. A. et al. Plant bugs (Heteroptera: Miridae) associated with roadside habitats in Argentina and Paraguay: host plant, temporal, and geographic range effects. Annals of the Entomological Society of America, v. 98, n. 5, p. 694-702, 2005.

MENDES, S. M. et al. A buva (Conyza spp.): pode ser considerada planta hospedeira de Spodoptera frugiperda e Helicoverpa armigera? Sete Lagoas: Embrapa Milho e Sorgo, 2016. (Comunicado técnico, 215).

MOLINARI, A. M.; GAMUNDI, J. C. La "chinche diminuta" Nysius simulans en soja. Oliveros: INTA EEA, 2010.
MORAES, R. C. B.; HADDAD, M. L. Software para análise faunística - Anafau. In: SIMPÓSIO DE CONTROle BiológiCO, 8., 2003, São Pedro. Resumos... Piracicaba: Sociedade Entomológica do Brasil, 2003. p. 195.

MOREIRA, M. S. et al. Resistência de Conyza canadensis e Conyza bonariensis ao herbicida glyphosate. Planta Daninha, v. 25, n. 1, p. 157-164, 2007.

NORRIS, R. F.; KOGAN, M. Ecology interactions between weeds and arthropods. Annual Review of Entomology, v. 50, n. 1, p. 479-503, 2005.

PANIZZI, A. R. Ecologia nutricional de insetos sugadores de sementes. In: PANIZZI, A. R.; PARRA, J. R. P. (Orgs.). Ecologia nutricional de insetos e suas implicações no manejo de pragas. São Paulo: Manole/CNPq, 1991. p. 253-287.

PANIZZI, A. R. Wild hosts of pentatomids: ecological significance and role in their pest status on crops. Annual Review of Entomology, v. 42, n. 1, p. 99-122, 1997.

PANIZZI, A. R. et al. Survivorship, larval development and pupal weight of Anticarsia gemmatalis (Hübner) (Lepidoptera: Noctuidae) feeding on potential leguminous host plants. Neotropical Entomology, v. 33, n. 5, p. 563567, 2004.

ROZA-GOMES, M. F. et al. Danos de Rhopalosiphum padi (L.) (Hemiptera: Aphididae) no trigo em função da duração e da densidade de infestação. Neotropical Entomology, v. 37, n. 5, p. 577-581, 2008.

SALVADORI, J. R.; TONET, G. E. L. Manejo integrado dos pulgões de trigo. Passo Fundo: Embrapa-CNPT, 2001. (Documentos, 34).

TREZZI, M. et al. Impact of Conyza bonariensis density and establishment period on soyabean grain yield, yield components and economic threshold. Weed Research, v. 55, n. 1, p. 34-41, 2015.

VARGAS, L. et al. Buva (Conyza bonariensis) resistente ao glyphosate na região Sul do Brasil. Planta Daninha, v. 25, n. 3, p. 573-578, 2007.

ZAMBRANO-NAVEA, C.; BASTIDA, F.; GONZALEZANDUJAR, J. L. A hydrothermal seedling emergence model for Conyza bonariensis. Weed Research, v. 53, n. 3, p. 213-220, 2013. 